\title{
KAJIAN ETNOZOOLOGI MASYARAKAT DESA HADIWAARNO KABUPATEN PACITAN DALAM KONSERVASI PENYU SEBAGAI BAHAN PENYUSUNAN BOOKLET PENYULUHAN MASYARAKAT
}

\author{
Dwi Setyawan $^{1}$, Fatchur Rohman ${ }^{1}$, Hedi Sutomo ${ }^{1}$ \\ ${ }^{1}$ Prodi Pendidikan Biologi-Pascasarjana Universitas Negeri Malang \\ e-mail: dwis091187@gmail.com.
}

\begin{abstract}
ABSTRAK
Penelitian bertujuan menganalisis pengaruh langsung dan tidak langsung antara latar belakang pendidikan, pengetahuan etnozoologi, status ekonomi keluarga, dan sikap terhadap pemanfaatan penyu oleh masyarakat desa Hadiwarno kabupaten Pacitan. Analisis data dibedakan menjadi deskriptif dan korelasional kausal dengan menggunakan statistik analisis jalur (path-analysis). Hasil penelitian korelasional kausal menunjukkan, yaitu 1) ada pengaruh tidak langsung pengetahuan etnozoologi melalui sikap, 2) ada pengaruh langsung pengetahuan etnozoologi terhadap pemanfaatan penyu, 3) ada pengaruh langsung sikap terhadap pemanfaatan penyu, 4) ada pengaruh langsung status ekonomi keluarga terhadap pemanfaatan penyu.
\end{abstract}

Kata kunci: booklet, etnozoologi, konservasi, Pacitan, penyu

Penyu merupakan hewan langka dunia, sehingga kepunahan penyu di Indonesia akan sangat merugikan Indonesia baik akibat kehilangan keanekaragaman hewan maupun posisi Indonesia di percaturan Internasional. Menurut Arshad (2003) Green Peace mengancam memboikot wisata ke Indonesia akibat pembantaian penyu di Bali tahun 1989, di tingkat Asean tahun 1997 telah ada perjanjian bersama untuk perlindungan penyu. Populasi penyu yang semakin menurun dilindungi dan masuk dalam kategori hewan yang terancam kepunahannya dan tertera dalam Red Data Book oleh IUCN (Internatinal Union for Conservation of Nature and Natural Resources) dan saat ini tercatat dalam Appendix I CITES (Convention on International Trade in Endangered Wild Flora Fauna Species). Konvensi tersebut melarang semua perdagangan internasional atas semua produk atau hasil dari penyu, baik itu telur, daging, maupun cangkangnya.

Indonesia merupakan negara kepulauan terbesar di dunia yang terdiri dari 17.508 pulau dengan garis pantai sepanjang $81.000 \mathrm{~km}$ dari luas laut sekitar 3,1 juta $\mathrm{km}^{2} \quad\left(0,3\right.$ juta $\mathrm{km}^{2}$ perairan territorial dari 2,8 juta $\mathrm{km}^{2}$ perairan nusantara) atau $62 \%$ dari luas teritorial. Wilayah pesisir dan lautan Indonesia terkenal dengan kekayaan keanekaragaman dan sumberdaya alamnya, baik sumberdaya yang tidak dapat pulih maupun yang dapat pulih. Kondisi ini merupakan habitat yang sesuai bagi penyu untuk singgah dan bereproduksi, sehingga menjadi daya tarik tersendiri bagi pantai kepulauan Indonesia, sekaligus penyu menjadi salah satu keanekaragaman yang dimiliki Indonesia. Hal tersebut menunjukkan bahwa di sekitar kelautan mempunyai potensi yang sangat besar dalam bangunan di masa depan (Dahuri, 2001). Banyaknya spesies hewan yang terindentifikasi, menjadikan Indonesia sebagai tujuan para peneliti untuk melakukan penelitian, karena itu melestarikan sumberdaya alam menjadi kewajiban seluruh lapisan masyarakat.

Troeng (1997) mengungkapkan bagi lingkungan, penyu merupakan salah satu komponen penting dari biodiversitas (keanekaragaman biologi), yang mana kepunahannya, akan menyebabkan ikut 
hilangnya komponen lain dan akan mengganggu fungsi biodiversitas yang ada. Di Indonesia terdapat 6 dari 7 jenis penyu yang ada di dunia. Dari 6 jenis penyu tersebut, 5 jenis diantaranya; yaitu penyu belimbing (Dermochelys coriacea), penyu hijau (Chelonia mydas), penyu sisik (Eremochelys imbricate), dan penyu lekang (Lepidochelys olivacea) telah diketahui berbiak di Indonesia, sementara jenis yang lain, penyu tempayan (Caretta caretta) diduga juga berbiak di Indonesia, jenis ke 6, penyu pipih (Natator epresus) diketahui hanya berbiak di Australia, tetapi telah teramati mencari makan di perairan Indonesia, namun sangat disayangkan Indonesia menjadi negara pembantai penyu terbesar di dunia (Kitchener 1996, dalam prihanta, 2007).

Usaha perlindungan penyu di Indonesia terus dilakukan oleh Pemerintah maupun kelompok pemerhati lingkungan. Salah satunya adalah meningkatkan pengawasan terhadap habitat yang sesuai untuk lokasi peneluran dan pengawasan pada penangkapan penyu. Secara formal, pemerintah Indonesia telah berusaha melindungi penyu dari kepunahan dengan Peraturan Pemerintah No 7 Tahun 1999 tentang Pengawetan Jenis Tumbuhan dan Satwa. Peraturan Pemerintah tersebut menetetapkan bahwa semua jenis penyu dilindungi. Beberapa tempat juga telah ditetapkan sebagai kawasan perlindungan penyu di Indonesia, di antaranya Taman Nasional Meru Betiri, Taman Nasional Alas Purwo, Suaka Margasatwa Jamursba Medi Irian Jaya, dan lain-lain. Usaha perlindungan dilakukan dengan menyelamatkan telur penyu di pantai, membesarkan, dan melepas ke laut. Namun, permasalahan yang muncul akibat kurang pengetahuan pelaksana dan pendanaan ternyata banyak telur penyu yang tidak menetas dan anak penyu yang mati selama perawatan (Pramoto, 2004).

Berdasarkan identifikasi di kabupaten Trenggalek dan Pacitan ditemukan, 4 jenis penyu yaitu: Dermochelys coriacea L, Chelonia mydas L, Eretmochelys imbricata
L, dan Lepidochelys olivaceae. Jumlah penyu yang ditemukan mengalami penurunan $28 \%$ dibandingkan tahun lalu. Masyarakat mendapatkan penyu dengan sengaja maupun tidak sengaja sebagai contoh terkena jaring ikan. Penyu maupun telur yang didapatkan sebagian di konsumsi dan sebagian lain dijual terutama Eretmochelys imbricata (Prihanta, 2007). Pengawasan penyu di luar kawasan konservasi tentunya tidak mudah, sebab perangkat hukum yang sering dilanggar ditambah dengan lemahnya penegakan hukum konservasi sangat sering terjadi. Diperlukan strategi penyelamatan penyu di luar kawasan konservasi yang mendapat dukungan luas dari masyarakat dan tetapa terjaga kelestariannya.

Kurniawati (2006) menyatakan masyarakat pesisir kecamatan Ngadirojo kabupaten Pacitan tidak secara detail mengetahui bahwa penyu merupakan hewan yang dilindungi. Masyarakat memanfaatkan penyu untuk kebutuhan sehari-hari, souvenir, maupun dikonsumsi. Masyarakat mendapatkan penyu dengan tidak sengaja maupun sengaja. Penangkapan dengan sengaja menggunakan kail dan tombak, adapula yang mendapatkan saat penyu betina bertelur. Penyu yang didapatkan didistribusikan di daerah setempat maupun ke daerah lainnya, namun sebenarnya secara adat penyu dianggap hewan keramat yang tidak sembarang orang dapat menyembelihnya, penyembelihan harus dilakukan oleh dukun dengan tatacara tertentu.

Berdasarkan hasil observasi peneliti pada bulan Juli 2013 di masyarakat desa Hadiwarno kabupaten Pacitan dikenal adanya mitos yang mengeramatkan penyu, penangkapan untuk konsumsi, perdagangan untuk kebutuhan ekonomi. Kurangnya pendidikan dan pengetahuan masyarakat tentang pentingnya penyu dalam ekosistem laut, sehingga sikap terhadap habitat dan fungsi penyu lebih cenderung ke arah eksploitasi. Pemanfaatan penyu secara berlebihan (over exploitation) akan 
mempercepat terjadi kepunahan, tidak hanya di Indonesia tapi hampir di seluruh belahan dunia, informasi penting yang belum tersedia untuk melindungi penyu secara utuh di daerah Pacitan adalah belum adanya informasi etnozoologi penyu di masyarakat. Informasi tersebut perlu diketahui sebagai dasar mengkampanyekan pelestarian penyu di Pacitan.

Ada beberapa faktor yang dapat dijadikan alasan, mengapa aktivitas masyarakat Pacitan dalam memanfaatkan penyu jauh dari kegiatan konservasi diantaranya adalah latar belakang pendidikan. Menurut UU RI No. 20 Tahun 2003 pasal 1, pada dasarnya jenjang pendidikan adalah tahapan pendidikan yang ditetapkan berdasarkan tingkat perkembangan peserta didik, tujuan yang akan dicapai, dan kemampuan yang dikembangkan. Pendidikan adalah aktivitas dan usaha untuk meningkatkan kepribadian dengan jalan membina potensi-potensi pribadinya yaitu rohami (pikir, cipta rasa dan hari nurani) serta jasmani (panca indera dan keterampilan).

Tingkat pengetahuan seseorang dipengaruhi oleh tingkat pendidikan, keaktifan mengikuti informasi dari media massa, keaktifan berorganisasi dan faktor ekonomi yang baik merupakan dasar bagi terbentuk sikap yang positif. Menurut Sutomo (2009) pengetahuan merupakan produk olah pikir manusia yang paling sederhana, yaitu sesuatu yang diketahuai oleh manusia, tanpa menghiraukan apakah benar atau salah dan juga tidak memasalahkan siapa, kapan dan dari mana sumbernya. Hasil "tahu" ini terjadi setelah orang melakukan penginderaan atau mempelajari terhadap suatu obyek tertentu yang dipengaruhi berbagai faktor dari dalam seperti motivasi dan faktor luar berupa sarana informasi yang tersedia serta keadaan sosial budaya. Pernyataan ini memberikan arti bahwa pengetahuan etnozoologi dalam konservasi dapat dijadikan sarana untuk mendapatkan pengetahuan dengan meningkatan pengetahuan diharapakan masyarakat di desa Hadiwarno kabupaten Pacitan mengalami perubahan sikap dalam memanfaatkan penyu.

Status ekonomi masyarakat pacitan berperan penting dalam unculnya sikap dan pemanfaatan penyu. Menurut Hamdanah (2010) status ekonomi merupakan kedudukan atau posisi seseorang dalam masyarakat berkaitan dengan tingkat pendidikan, tingkat pendapatan, kepemilikan kekayaan atau fasilitas serta jenis tempat tinggal. Kondisi sosial ekonomi masyarakat juga menentukan tingkat pendapatan dan keberhasilan seseorang dalam masyarakat, tingkat pendidikan masyarakat akan berpengaruh terhadap keberhasilan masyarakat. Semakin tinggi tingkat pendidikan masyarakat, maka semakin terampil dan berhasil dalam pekerjaan, sehingga berpengaruh terhadap tingkat pendapatan.

Sikap adalah sebagai salah satu fungsi instrumental atau fungsi manfaat akan positif bila ada manfaatnya. Sikap hanya akan ada artinya apabila diwujudkan dalam bentuk tingkah laku, sedangkan tingkah laku ini selalu didasarkan pada persepsi terhadap suatu obyek. Sebaliknya, persepsi seseorang terhadap suatu objek atau lingkungannya ditentukan oleh kebutuhannya, sedangkan perilaku merupakan fungsi dari faktor internal dalam diri seseorang dan lingkungan yang mempengaruhinya (Azwar, 2007). Tingkat pengetahuan, sikap sangat mempengaruhi perilaku, dan peran serta masyarakat terhadap sumberdaya alam; contoh respon masyarakat terhadap pengelolaan sumberdaya alam. Dari berbagai kemungkinan tersebut, muncul fenomena pemanfaatan penyu oleh masyarakat pacitan. Pemanfaatan memiliki kata dasar manfaaat yang berarti faedah atau guna. Ada 4 macam pemanfaatan, yaitu: (1) Manfaat langsung, yaitu manfaat yang langsung dapat dinikmati, dipakai atau digunakan sebab adanya investasi, baik berupa kenaikan fisik hasil produksi, perbaikan kualitas fisik hasil produksi, perbaikan kualitas produksi atau pun 
penurunan biaya, (2) Manfaat peralihan, yaitu manfaaat latihan yang dapat meningkatkan kemampuan dan kesediaan untuk bekerja, (3) Manfaat terpakai, yaitu manfaat dari bagian aktiva tetap yang telah hilang, (4) Manfaaat tidak langsung, yaitu manfaat lain yang timbul olehkarena adanya suatu investasi tau sebab-sebab lain yang ada diluar perhitungan.

Perlu adanya tindakan untuk merubah pemanfaatan penyu oleh masyarakat desa Hadiwarno dari eksploitasi menjadi kegiatan konservasi. Putra (1997) mengungkapkan penyuluhan sebagai kegiatan pemberdayaan masyarakat yang telah mulai lazim digunakan oleh banyak pihak sejak awal dasawarsa 1990-an. Penyuluhan sebagai proses pemberdayaan masyarakat, memiliki tujuan utama yang tidak terbatas pada terciptanya "better living”, tetapi untuk memfasilitasi masyarakat (sasaran) untuk mengadopsi strategi agar mempercepat terjadinya perubahan-perubahan kondisi sosial dan ekonomi, sehingga mereka dapat (dalam jangka panjang) meningkatkan taraf hidup pribadi dan masyarakatnya. Penyuluhan tidak sekadar upaya untuk menyampaikan pesan-pesan, tetapi yang lebih penting dari itu adalah untuk menumbuh kembangkan partisipasi masyarakat dalam konservasi penyu. Pendidikan merupakan salah satu pilar terpenting dalam meningkatkan kualitas hidup manusia. Pendidikan nonformal adalah cara pembelajaran yang tepat dalam masyarakat, memiliki kelebihan yaitu fleksibilitas waktu sehingga tidak menyita kesibukan masyarakat desa.

Booklet merupakan sarana atau alat penunjang yang tepat untuk pendidikan nonformal. Booklet merupakan buku berukuran kecil (setengah kuarto) dan tipis, tidak lebih dari 30 halaman bolak-balik, yang berisi tulisan atau penjelasan singkat dan gambar-gambar yang bertujuan memudahkan pembaca dalam memahami isi bacaan. Ada yang mengatakan bahwa istilah booklet berasal dari buku dan leaflet, artinya media booklet merupakan perpaduan antara leaflet dengan buku atau sebuah buku dengan format kecil seperti leaflet. Struktur isinya seperti buku (ada pendahulu, isi, dan penutup) hanya saja cara penyajian isinya jauh lebih singkat daripada sebuah buku (Hariri, 1999).

Fenomena yang muncul dari pemanfaatan penyu oleh masyarakat desa Hadiwarno kabupaten Pacitan diketahui bertolak belakang dengan kondisi idealnya bahwa penyu merupakan hewan yang dilindungi, karena bagi sebagian masyarakat, penyu telah memberikan pekerjaan dan sumber pendapatan, sehingga kebutuhan penyu yang tinggi dalam masyarakat sangat memprihatinkan. Namun saat ini peneliti sangat minim menemukan hasil penelitian mengenai penyu yang berhubungan dengan masyarakat Pacitan tersebut, untuk itu perlu adanya suatu penelitian yang mengungkap dan menjawab pertanyaan bagaimana hubungan timbal balik antara manusia dan hewan penyu (Etnozoologi) dalam lingkungan masyarakat Pacitan.

Adapun hal-hal yang dikaji dalam penelitian ini adalah mengenai latar belakang pendidikan, pengetahuan etnozoologi, status ekonomi, sikap, dan pemanfaatan penyu oleh masyarakat di desa Hadiwarno kabupaten Pacitan. Berdasarkan kenyataan tersebut usaha penyelamatan penyu laut di Pacitan adalah dengan meningkatkan kesadaran masyarakat pada perlindungan penyu. Hal itu dilakukan dengan memperhatikan etnozoologi masyarakat setempat, maka perlu mengetahui pengetahuan dan pemanfaatan yang menjadi dasar timbulnya kecendrungan untuk memanfaatkan hewan yang dilindungi terebut. Oleh karena itu, peneliti menganggap sangat penting untuk dilakukan penelitian "kajian etnozoologi masyarakat desa Hadiwarno kabupaten Pacitan dalam konservasi penyu sebagai bahan penyusunan booklet untuk penyuluhan masyarakat".

Penelitian ini memiliki tujuan yaitu; 1) menganalisis pengaruh langsung dan tidak langsung antara latar belakang pendidikan terhadap pemanfaatan penyu di 
desa Hadiwarno kabupaten Pacitan, 2) menganalisis pengaruh langsung dan tidak langsung antara pengetahuan etnozoologi terhadap pemanfaatan penyu di desa Hadiwarno kabupaten Pacitan, 3) menganalisis pengaruh langsung dan tidak langsung antara setatus ekonomi keluarga terhadap pemanfaatan penyu di desa Hadiwarno kabupaten Pacitan, 4) menganalisis pengaruh langsung dan tidak langsung antara sikap terhadap pemanfaatan penyu di desa Hadiwarno kabupaten Pacitan, 5) mengembangkan hasil penelitian sebagai bahan penyusunan booklet untuk penyuluhan masyarakat di desa Hadiwarno kabupaten Pacitan.

\section{METODE}

Jenis penelitian korelasional kausal dengan menggunakan statistik analisis jalur (path-analysis). Suatu variabel tidak hanya dijelaskan keterkaitannya terhadap variabel lain, tetapi juga perlu dideskripsikan. Variabel-variabel penelitian mencakup latar belakang pendidikan, pengetahuan etnozoologi, status ekonomi keluarga, sikap, dan pemanfaatan penyu di desa Hadiwarno kabupaten Pacitan.

Populasi sampling dalam penelitian ini adalah Kepala Keluarga (KK) masyarakat di dusun Taman desa Hadiwarno, yang berprofesi sebagai nelayan dan pengelola konservasi penyu. Karena, profesi tersebut hanya ada di dusun Taman desa Hadiwwarno. Populasi sasaaran dalam penelitian ini adalah seluruh Kepala Keluarga (KK) di dusun taman desa Hadiwarno, yang jumlah Kepala Keluarganya melebihi ketentuan jumlah sampel, yaitu lebih dari 50-100 orang. Besar populasi sampling sejumlah 150 orang. Sampel penelitian ini adalah Kepala Keluarga (KK) dari masyarakat dusun Taman desa Hadiwarno kabupaten Pacitan. Penentuan sampel (teknik sampling) menggunakan teknik (probability sampling atau random sampling) sampel acak sederhana, yaitu dengan cara diundi dari jumlah populasi sebesar 150 KK nelayan dan pengelola konservasi penyu. Penentuan jumlah sampel (besar sampel) dalam penelitian ini menggunakan metode standard error untuk proporsi (presentase), batas probabilitas $95 \%$, standard error $\pm 10 \%$, akan menyebabkan 1,96 $\sigma$ standard deviatiaon untuk proporsi 50\%:50\%.

Instrumen untuk mengukur latar belakang pendidikan masyarakat desa Hadiwarno kabupaten Pacitan ialah keusioner yang menanyakan lama waktu dalam menempuh pendidikan formal (Zaini, 2005). Instrumen untuk mengukur pengetahuan entozoologi adalah tes pengetahuan dengan indikator empiris mengetahui (C1), memahami (C2), dan menerapkan (C3). Instrumen yang digunakan untuk mengukur status ekonomi keluarga adalah kuesioner yang menanyakan indeks kelas ekonomi berdasarkan kepemilikan barang berharga. Instrumen yang digunakan untuk mengukur sikap adalah tes sikap dengan parameter kognisi, afeksi, dan konasi. Instrumen untuk mengukur pemanfaatan penyu adalah pengamatan langsung dan wawancara terstruktur mengenai pemanfaatan penyu secara positif maupun secara negatif. Kegiatan pengembangan instrumen penelitian harus terlebih dahulu merumuskan, menyusun validitas logis, dan menetapkan skor setiap variabel penelitian.

Pengumpulan data dilakukan melalui 2 tahap kegiatan. Rangkaian pengumpulan data yang tersusun secara sistematis dimulai dari persiapan dan teknik pengumpulan data, pelaksanaan pengumpulan data dan kualifikasi jumlah petugas. Pada tahap persiapan peneliti melakukan observasi (studi pendahuluan) pada lokasi penelitian, alasan menggunakan observasi agar mengetahui secara langsung tentang sumber data yang akan diteliti dan dapat memperoleh data yang kongkrit, dengan cara berkunjung dan berdomisili selama 3 bulan atau lebih yang bertujuan untuk mengetahui kondisi lingkungan, budaya, dan sosial masyarakat tempat penelitian. Selanjutnya, penentuan 
responden untuk pengambilan data dengan simple random sampling yaitu dengan cara diundi, untuk mendapatkan jumlah responden sejumlah 96 orang dari 150 orang yang berprofesi sebagai nelayan dan pengelola konserfasi penyu di desa Hadiwarno kabupaten Pacitan. (2) Teknik pengumpulan data, dari masing-masing instrumen dilakukan dengan cara memberikan tes dalam bentuk quesioner, wawancara, dan pengamatan langsung, a) data pengetahuan etnozoologi masyarakat dikumpulkan melalui tes tentang pengetahuan etnozoologi, b) data sikap masyarakat dikumpulkan melalui tes sikap masyarakat tentang pemanfaatan penyu, c) data latar belakang pendidikan dikumpulkan melalui wawancara mengenai pendidikan yang sudah ditempuh masyarakat, d) data status ekonomi keluarga masyarakat dikumpulkan melalui wawancara mengenai kepemilikan barang berharga, e) data perilaku masyarakat terkait pemanfaatan penyu (secara positif dan negatif) dikumpulkan melalui pengamatan langsung.

Proses yang berkaitan dengan pelaksanaan penelitian sebagai berikut. a) melakukan perijinan dengan pihak terkait, b) terjun ke lokasi penelitian untuk memperoleh data, c) melakukan pendekatan dengan metode diskusi (Focus Group Discussion) bersama responden adapun tujuan kegiatan FGD adalah untuk memperoleh keterangan nyata dari responden, mengklarifikasi informasi yang salah atau kurang pada kegiatan wawancara, mencari kebenaran tentang pengetahuan etnozoologi, sikap, dan pemanfaatan penyu di masyarakat desa Hadiwarno kabupaten Pacitan. (2) Pengambilan data dilakukan oleh peneliti sendiri, dibantu oleh 1 orang dari anggota masyarakat yang kualifikasinya tertentu, dengan dilatih terlebih dahulu. Informan kunci berperan penting dalam penelitian, yang bertugas sebagai penunjukkan tempat rumah masing-masing responden dan sebagai supervisor dalam membantu memeriksa kelengkapan instrumen.
Analisis data bertujuan untuk menjawab tujuan penelitian yang telah dirumuskan, dibedakan atas 2 cara, yaitu; 1) deskripsi data bertujuan mengungkap data latar belakang pendidikan, pengetahuan etnozoologi, status ekonomi keluarga, sikap, dan pemanfaatan penyu diolah dengan teknik statistik deskriptif, tabel frekuensi dan grafik. 2) pengujian hipotesis menggunakan statistik korelasional kausal dengan menggunakan analisis jalur (path analysis) metode trimming dengan terlebih dahulu menentukan diagram jalur sesuai teori, maka dapat disusun model hubungan dalam penelitian ini sebanyak 2 blok, spesifikasi model analisis jalurnya dapat dilihat pada Gambar 1.

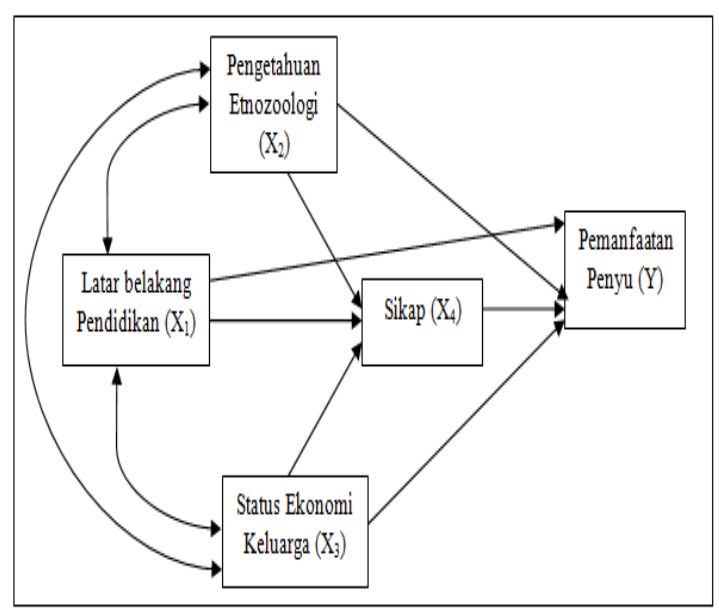

Gambar 1. Variabel-variabel Penelitian dan Pola Hubungan Antarvariabel

Tahapan dalam Analisis data perlu dilakukan uji persyaratan (asumsi). Pengujian tersebut dilakukan dengan bantuan paket program SPSS For Windows versi 21.

\section{HASIL}

\section{Pengujian Hipotesis}

Pergeseran Hubungan Kausal Antarvariabel

Terjadi pergeseran hubungan kausal antarvariabel latar belakang pendidikan, pengetahuan etnozoologi, status ekonomi keluarga, dan sikap terhadap pemanfaatan penyu dapat dilihat pada Gambar 2. 


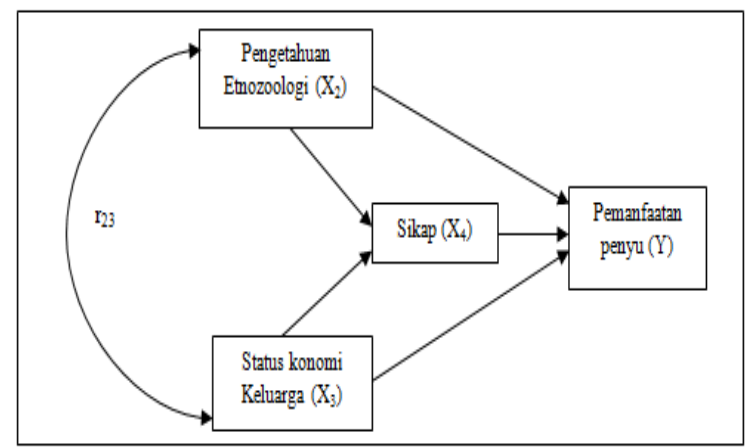

Gambar 2. Hubungan kausal antarvariabel $X_{2}$, $\mathbf{X}_{3}, \mathbf{X}_{4}$, terhadap $\mathbf{Y}$

\section{Hubungan antara Variabel Eksogen}

Hubungan antara variabel eksogen Pengetahuan Etnozoologi $\left(\mathrm{X}_{2}\right)$ dan Status Ekonomi Keluarga $\left(\mathrm{X}_{3}\right)$ data dapat dilihat pada Tabel 1.

Tabel 1. Matrik Korelsi X2 dan X3.

\begin{tabular}{|c|c|c|c|}
\hline & & $\begin{array}{l}\text { Pengeta-huan } \\
\text { Etnozoologi } \\
\text { (X2) }\end{array}$ & $\begin{array}{c}\text { Status } \\
\text { Ekonomi } \\
\text { Keluarga } \\
\text { (X3) }\end{array}$ \\
\hline \multirow{4}{*}{$\begin{array}{l}\text { Pengetahuan } \\
\text { Etnozoologi } \\
\text { (X2) }\end{array}$} & Pearson & 1 & $-0,046$ \\
\hline & $\begin{array}{l}\text { Correla- } \\
\text { tion }\end{array}$ & & \\
\hline & $\begin{array}{l}\text { Sig. (2- } \\
\text { tailed) }\end{array}$ & & 0,654 \\
\hline & $\mathrm{N}$ & 96 & 96 \\
\hline \multirow{3}{*}{$\begin{array}{l}\text { Status Ekonomi } \\
\text { Keluarga (X3) }\end{array}$} & $\begin{array}{l}\text { Pearson } \\
\text { Correla- } \\
\text { tion }\end{array}$ & $-0,046$ & 1 \\
\hline & $\begin{array}{l}\text { Sig. }(2- \\
\text { tailed) }\end{array}$ & 0,654 & \\
\hline & $\mathrm{N}$ & 96 & 96 \\
\hline
\end{tabular}

Hasil pengujian hipotesis, diperoleh tidak ada hubungan antara pengetahuan etnozoologi Dari hasil pengujian mengenai hubungan antara variabel eksogenus, maka diperoleh Gambar 3.

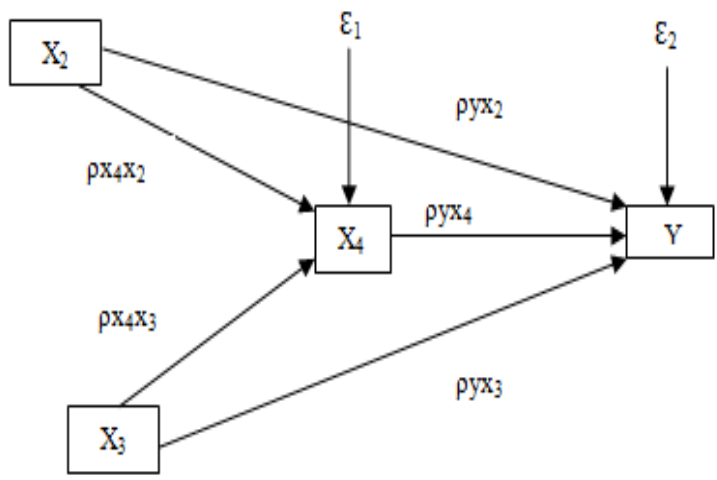

Gambar 3. Hubungan Struktural $X_{2}, X_{3}, X_{4}$, terhadap $Y$

\section{Analisis Blok 1}

Pengujian hipotesis pengaruh pengetahuan etnozoologi $\left(\mathrm{X}_{2}\right)$ dan status ekonomi keluarga $\left(\mathrm{X}_{3}\right)$ terhadap sikap $\left(\mathrm{X}_{4}\right)$ diperoleh seperti Tabel 2.

Tabel 2. Anova Blok 1 Model 1

\begin{tabular}{llccccc}
\hline Model & & $\begin{array}{c}\text { Sum of } \\
\text { Squares }\end{array}$ & Df & $\begin{array}{c}\text { Mean } \\
\text { Square }\end{array}$ & F & Sig. \\
\hline & Regressio & 68,217 & 2 & 34,108 & 2,159 & 0,121 \\
1 & $\mathrm{n}$ & & & & & $\mathrm{b}$ \\
& Residual & 1469,273 & 93 & 15,799 & & \\
& Total & 1537,490 & 95 & & & \\
\hline
\end{tabular}

a. Dependent Variabel: Sikap $\left(\mathrm{X}_{4}\right)$

b. Predictors: (Constant), Status Ekonomi Keluarga ( $\left.\mathrm{X}_{3}\right)$, Pengetahuan Etnozoologi $\left(\mathrm{X}_{2}\right)$

Tabel 2 anova, diperoleh nilai $\mathrm{F}$ sebesar 2,159 dengan nilai signifikansi $($ probabilitas $)=0,121>0,05$. Hipotesis yang menyatakan bahwa Ho yang menyatakan ada pengaruh pengetahuan etnozoologi dan status ekonomi keluarga terhadap sikap diterima. Sehingga dilanjutkan dengan pengujian individu.

Pengujian individu diperoleh hasil yaitu; a) pengaruh pengetahuan etnozoologi terhadap sikap adalah $\rho_{\mathrm{X}_{4} \mathrm{X}_{2}}=$ Beta $=0,210$ $[\mathrm{t}=2,072$ dan probabilitas signifikan $=$ 0,041], b) pengaruh status ekonomi keluarga terhadap sikap adalah $\rho_{\mathrm{X}_{4} \mathrm{X}_{3}}=$ Beta $=-0,006 \quad[\mathrm{t}=-0,062$ dan probabilitas signifikan $=0,951]$. Dari perhitungan di atas dapat menjelaskan, bahwa hasil analisis blok 1 model 1 mengungkapkan bahwa ada koefisien jalur yang tidak signifikan yaitu variabel status ekonomi keluarga $\left(\mathrm{X}_{3}\right)$, maka blok 1 model 1 perlu diperbaiki melalui metode trimming, yaitu menguji ulang variabel pengetahuan etnozoologi $\left(\mathrm{X}_{2}\right)$ dan tidak mengikutkan variabel status ekonomi keluarga $\left(\mathrm{X}_{3}\right)$.

Pengujian ulang "Pengaruh pengetahuan etnozoologi terhadap sikap". Diperoleh hasil seperti Tabel 3.

Tabel 3. Anova Blok 1 Model 2

\begin{tabular}{|c|c|c|c|c|c|c|}
\hline \multicolumn{2}{|c|}{ Model } & $\begin{array}{l}\text { Sum of } \\
\text { Squares }\end{array}$ & Df & $\begin{array}{l}\text { Mean } \\
\text { Square }\end{array}$ & $\mathrm{F}$ & Sig. \\
\hline \multirow{3}{*}{2} & Regression & 68,156 & 1 & 68,156 & 4,360 & $0,039^{\mathrm{b}}$ \\
\hline & Residual & 1469,334 & 94 & 15,631 & & \\
\hline & Total & 1537,490 & 95 & & & \\
\hline
\end{tabular}


Tabel 3 Anova, diperoleh nilai $\mathrm{F}$ sebesar 4,360 dengan nilai signifikansi (probabilitas $)=0,039<0,05$, maka dapat disimpulkan bahwa: Ha yang menyatakan ada pengaruh pengetahuan etnozoologi $\left(\mathrm{X}_{2}\right)$ terhadap sikap $\left(\mathrm{X}_{4}\right)$ diterima.

Tabel 4. Coefficients Blok 1 Model 2

\begin{tabular}{|c|c|c|c|c|c|c|}
\hline \multirow{2}{*}{\multicolumn{2}{|c|}{ Model }} & \multicolumn{2}{|c|}{$\begin{array}{l}\text { Unstandardized } \\
\text { Coefficients }\end{array}$} & $\begin{array}{c}\text { Standardize } \\
\mathrm{d} \\
\text { Coefficient } \\
\mathrm{s}\end{array}$ & \multirow[t]{2}{*}{$\mathrm{T}$} & \multirow[t]{2}{*}{ Sig. } \\
\hline & & B & $\begin{array}{l}\text { Std. } \\
\text { Error }\end{array}$ & Beta & & \\
\hline \multirow[t]{2}{*}{2} & $\begin{array}{l}\text { (Cons } \\
\text { tant) }\end{array}$ & 132,843 & 2,704 & & $\begin{array}{c}49,12 \\
0\end{array}$ & 0,000 \\
\hline & (X2) & 0,306 & 0,147 & 0,211 & 2,088 & 0,039 \\
\hline
\end{tabular}

Berdasarkan Tabel 4 di atas, diperoleh nilai koefisien jalur $X_{2}$ terhadap $\mathrm{X}_{4}$ sebesar $\rho_{\mathrm{X} 4 \mathrm{X} 2}=0,211$.

Tabel 5. Summary Blok 1 Model 2

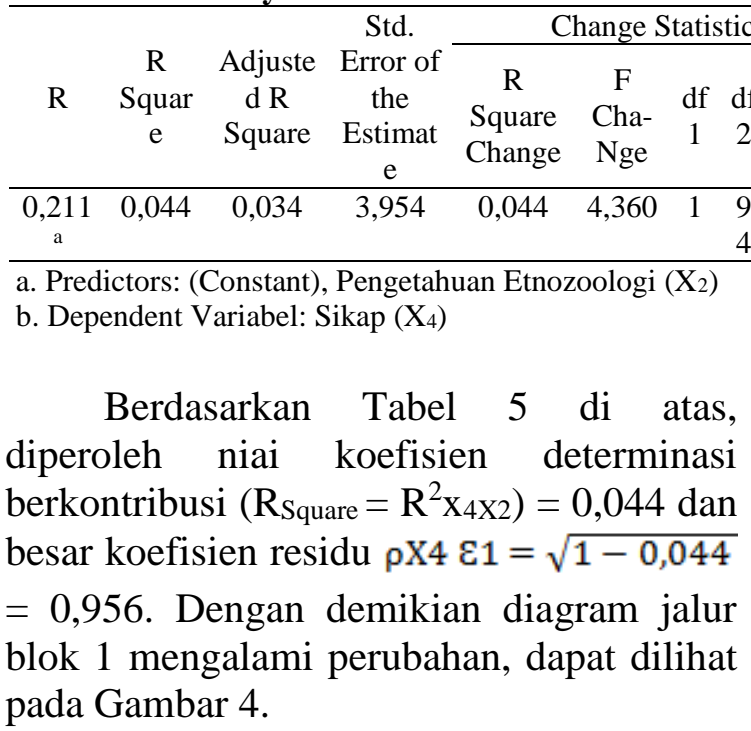

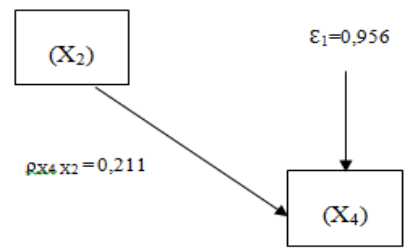

Gambar 4. Pengaruh Empiris Blok 1 Variabel $X_{2}$ terhadap $\mathrm{X}_{4}$

\section{Analisis Blok 2}

Pengaruh pengetahuan etnozoologi $\left(\mathrm{X}_{2}\right)$, status ekonomi keluarga $\left(\mathrm{X}_{3}\right)$, dan sikap $\left(\mathrm{X}_{4}\right)$ terhadap pemanfaatan penyu $(\mathrm{Y})$ diperoleh seperti Tabel 6.
Tabel 6. Anova Blok 2 Model 1

\begin{tabular}{lllllll}
\hline Model & & $\begin{array}{c}\text { Sum of } \\
\text { Squares }\end{array}$ & Df & $\begin{array}{c}\text { Mean } \\
\text { Square }\end{array}$ & F & Sig. \\
\hline \multirow{4}{*}{1} & Regression & 418,030 & 3 & 139,343 & 5,911 & $0,001^{\mathrm{b}}$ \\
& Residual & 2168,595 & 92 & 23,572 & & \\
& Total & 2586,625 & 95 & & & \\
\hline a. Dependent Variabel: Pemanfaatan Penyu (Y) \\
b. Predictors: (Constant), Sikap $\left(\mathrm{X}_{4}\right)$, Status Ekonomi Keluarga $\left(\mathrm{X}_{3}\right)$, \\
Pengetahuan Etnozoologi $\left(\mathrm{X}_{2}\right)$
\end{tabular}

Tabel 6 Anova, diperoleh nilai $\mathrm{F}$ sebesar 5,911 dengan nilai (probabilitas) $=$ $0,001<0,05$, maka dapat disimpulkan bahwa: Ha yang menyatakan bahwa ada pengaruh pengetahuan etnozoologi, status ekonomi keluarga, dan sikap terhadap pemanfaatan penyu diterima.

Besarnya nilai signifikansi yang diperoleh $(0,001<0,05)$, maka pengujian secara individual masing-masing variabel eksogenus, dapat dilakukan atau dilanjutkan. Hasil pengujian individu tentang Coefisien Blok 2 model 1 dapat dilihat pada Tabel 7 .

\section{Sig. F}

Cha-Tabel 7. Coefficients Blok 2 Model 1

\begin{tabular}{ccccccc}
\hline Model & \multicolumn{2}{c}{$\begin{array}{c}\text { Unstandardized } \\
\text { Coefficients }\end{array}$} & $\begin{array}{c}\text { Standardized } \\
\text { Coefficients }\end{array}$ & T & Sig. \\
\cline { 3 - 6 } & \multicolumn{2}{c}{ B } & Std. Error & Beta & & \\
\hline \multirow{2}{*}{1} & (Constant) & 20,326 & 17,225 & & 1,180 & 0,241 \\
& $\left(\mathrm{X}_{2}\right)$ & 0,465 & 0,184 & 0,247 & 2,524 & 0,013 \\
\hline & $\left(\mathrm{X}_{3}\right)$ & 0,003 & 0,002 & 0,198 & 2,072 & 0,041 \\
\hline & $\left(\mathrm{X}_{4}\right)$ & 0,276 & 0,127 & 0,213 & 2,179 & 0,032 \\
\hline
\end{tabular}

a. Dependent Variabel: Pemanfaatan Penyu (Y)

Adapun besarnya pengaruh bersama variabel pengetahuan etnozoologi, status ekonomi keluarga, dan sikap terhadap pemanfaatan penyu dapat dilihat pada Tabel 8.

Tabel 8. Summary Blok 2 Model 1

\begin{tabular}{|c|c|c|c|c|c|c|c|c|}
\hline \multirow[b]{2}{*}{$\mathrm{R}$} & \multirow[b]{2}{*}{$\begin{array}{c}\mathrm{R} \\
\text { Square }\end{array}$} & \multirow[b]{2}{*}{$\begin{array}{c}\text { Adjusted } \\
\text { R } \\
\text { Square }\end{array}$} & \multirow{2}{*}{$\begin{array}{l}\text { Std. } \\
\text { Error } \\
\text { of the } \\
\text { Esti- } \\
\text { Mate }\end{array}$} & \multicolumn{5}{|c|}{ Change Statistics } \\
\hline & & & & $\begin{array}{c}\text { R } \\
\text { Square } \\
\text { Change }\end{array}$ & $\begin{array}{c}\text { F } \\
\text { Cha- } \\
\text { Nge }\end{array}$ & $\begin{array}{l}\text { D } \\
\mathrm{f} \\
1\end{array}$ & $\begin{array}{c}\mathrm{df} \\
2\end{array}$ & $\begin{array}{l}\text { Sig. F } \\
\text { Cha- } \\
\text { Nge }\end{array}$ \\
\hline $0,412^{\mathrm{a}}$ & 0,162 & 0,134 & 4.855 & 0,162 & 5.911 & 3 & 92 & 0,001 \\
\hline
\end{tabular}

Tabel 8 diperoleh nilai korelasi bersama kuadrat $\left(\mathrm{R}^{2}\right)$ variabel pengetahuan etnozoologi $\left(\mathrm{X}_{2}\right)$, status ekonomi keluarga $\left(\mathrm{X}_{3}\right)$, dan sikap $\left(\mathrm{X}_{4}\right)$ terhadap variabel pemanfaatan penyu (Y) sebesar 0,162 dan 
nilai residu sebesar $\sqrt{1-0,162}=0,838$. Disimpulkan pengetahuan etnozoologi, status ekonomi keluarga, dan sikap berpengaruh terhadap pemanfaatan penyu sebesar 16,2\%, variabel lain juga berpengaruh terhadap sikap sebesar $83,8 \%$ dan tidak dapat dijelaskan dalam penelitian.

Pengujian Blok 2 model 2 "Pengaruh status ekonomi keluarga $\left(\mathrm{X}_{3}\right)$ dan sikap $\left(\mathrm{X}_{4}\right)$ terhadap pemanfaatan penyu (Y)". Hasil pengujian dapat dilihat pada Tabel 9.

Tabel 9. Anova Blok 2 Model 2

\begin{tabular}{|c|c|c|c|c|c|c|}
\hline \multicolumn{2}{|c|}{ Model } & $\begin{array}{l}\text { Sum of } \\
\text { Squares }\end{array}$ & Df & $\begin{array}{l}\text { Mean } \\
\text { Square }\end{array}$ & $\mathrm{F}$ & Sig. \\
\hline \multirow{3}{*}{2} & $\begin{array}{l}\text { Regressio } \\
\mathrm{n}\end{array}$ & 267,821 & 2 & 133,910 & 5,371 & $\underset{\mathrm{b}}{0,006}$ \\
\hline & Residual & 2318,804 & 93 & 24,933 & & \\
\hline & Total & 2586,625 & 95 & & & \\
\hline
\end{tabular}

a. Dependent Variabel: Pemanfaatan Penyu (Y)

b. Predictors: (Constant), Sikap ( $\left.\mathrm{X}_{4}\right)$, Status Ekonomi Keluarga $\left(\mathrm{X}_{3}\right)$

Berdasarkan Tabel 9 Anova, diperoleh nilai $\mathrm{F}$ sebesar 5,371 dengan nilai signifikansi (probabilitas) $=0,006<0,05$, maka dapat disimpulkan bahwa: Ha yang menyatakan ada pengaruh status ekonomi keluarga $\left(\mathrm{X}_{3}\right)$ dan sikap $\left(\mathrm{X}_{4}\right)$ terhadap pemanfaatan penyu $(\mathrm{Y})$ diterima pada taraf signifikan $\mathrm{p}=0,006<0,05$.

Tabel 10. Coefficients Blok 2 Model 2

\begin{tabular}{|c|c|c|c|c|c|c|}
\hline \multirow{2}{*}{\multicolumn{2}{|c|}{ Model }} & \multicolumn{2}{|c|}{$\begin{array}{l}\text { Unstandardized } \\
\text { Coefficients }\end{array}$} & $\begin{array}{l}\text { Standar } \\
\text { dized }\end{array}$ & \multirow[t]{2}{*}{$\mathrm{t}$} & \multirow[t]{2}{*}{ Sig. } \\
\hline & & B & $\begin{array}{l}\text { Std. } \\
\text { Error }\end{array}$ & Beta & & \\
\hline \multirow{4}{*}{2} & (Cons & 19,666 & 17,714 & & 1,110 & 0,270 \\
\hline & $\operatorname{tant})$ & & & & & \\
\hline & $\left(\mathrm{X}_{2}\right)$ & 0,003 & 0,002 & 0,187 & 1,908 & 0,059 \\
\hline & $\left(\mathrm{X}_{3}\right)$ & 0,343 & 0,127 & 0,265 & 2,695 & 0,008 \\
\hline
\end{tabular}

a. Dependent Variabel: Pemanfaatan Penyu (Y)

Adapun besar koefisien residu dapat dilihat pada Tabel 11.
Berdasarkan Tabel 11 di atas, diperoleh besar nilai koefisien residu untuk pyE2 $=\sqrt{1-0,104}=0,896$.

Dengan demikian diagram jalur blok 2 mengalami perubahan, dapat dilihat pada Gambar 5.

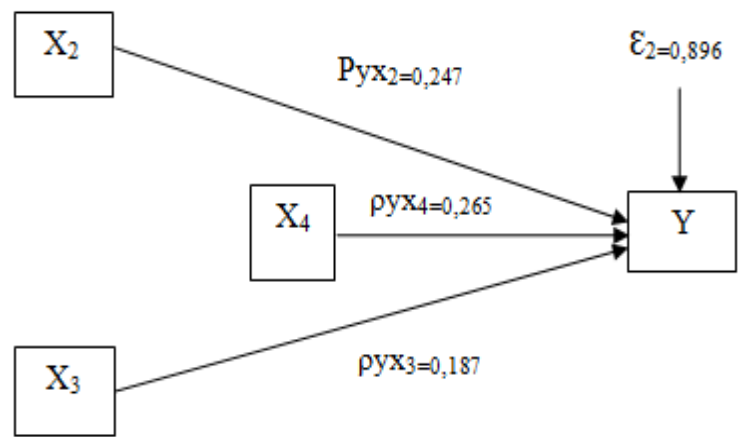

Gambar 5. Pengaruh Blok 2 Model 2 Variabel X2, X3, dan X4 terhadap Y

Berdasarkan hasil dari koefisien jalur blok 1 model 2 dan jalur blok 2 model 2, maka dapat digambarkan secara keseluruhan hubungan kausal empiris antara variabel $\mathrm{X}_{2}, \mathrm{X}_{3}$, dan $\mathrm{X}_{4}$ terhadap $\mathrm{Y}$ seperti Gambar 6.

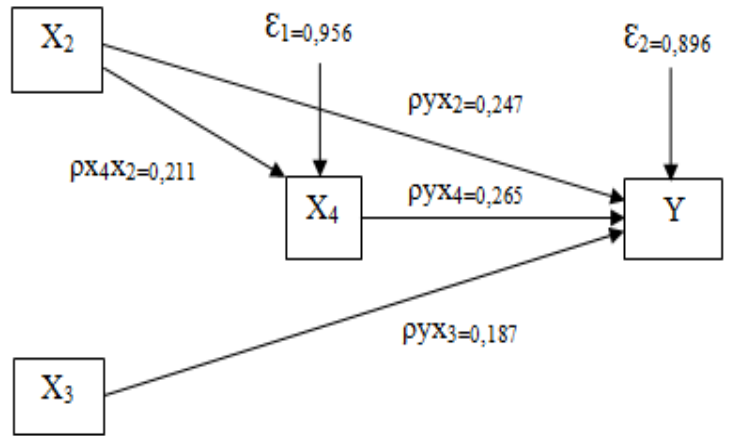

Gambar 6. Hubungan Kausal Variabel X2, X3, dan X4 terhadapY

Tabel 12. Ringkasan Hasil Perhitungan Pengaruh kausal terhadap Pemanfaatan Penyu

\begin{tabular}{|c|c|c|c|c|c|}
\hline \multirow[b]{2}{*}{ Variabel } & \multirow[b]{2}{*}{$\begin{array}{c}\text { Koefisien } \\
\text { Jalur }\end{array}$} & \multicolumn{3}{|c|}{ Pengaruh } & \multirow[b]{2}{*}{$\begin{array}{l}\text { Pengaruh } \\
\text { Bersama }\end{array}$} \\
\hline & & Langsung & $\begin{array}{c}\text { Tidak } \\
\text { Langsung } \\
\text { Melalui } \\
\mathrm{X}_{4}\end{array}$ & Total & \\
\hline $\mathrm{X} 2$ & 0,247 & 0,247 & 0,211 & 0,06 & - \\
\hline X3 & 0,187 & 0,187 & - & 0,187 & - \\
\hline $\mathrm{X} 4$ & 0,265 & $\begin{array}{c}0,265 \\
0,956^{2}=\end{array}$ & - & 0,256 & - \\
\hline$\varepsilon_{1}$ & 0,956 & $\begin{array}{c}0,91 \\
0,896^{2}=\end{array}$ & - & - & - \\
\hline $\begin{array}{c}\mathcal{E}_{2} \\
\mathrm{X} 3 \text { dan }\end{array}$ & 0,896 & 80,28 & - & - & - \\
\hline X4 & - & - & - & - & 1,08 \\
\hline
\end{tabular}




\section{PEMBAHASAN}

\section{Pembahasan Tahap 1: Hasil Penelitian Korelasional Kausal Jalur Blok 1}

Hasil uji korelasional kausal dengan menggunakan analisis jalur (path-analysis) "terdapat pengaruh pengetahuan etnozoologi $\left(\mathrm{X}_{2}\right)$ melalui sikap $\left(\mathrm{X}_{4}\right)$ terhadap pemanfaatan penyu (Y)". Dari hasil perhitungan diperoleh besar pengaruh pengetahuan etnozoologi 4,45\%. Artinya variabel lain juga berpengaruh terhadap pemanfaatan penyu sebesar 91,39\%, pengaruh variabel lain dalam hal ini dapat ditelusuri oleh peneliti adalah kurangnya penyuluhan pentingnya melestarikan dan melindungi penyu oleh pemerintah pacitan dan kurangnya pemahaman masyarakat Hadiwarno tentang larangan mengeksploitasi penyu. Pengaruh lainnya sebesar $4,16 \%$ adalah sikap. Pengaruh tersebut dalam hal ini yang dapat ditelusuri oleh peneliti adalah adanya contoh langsung yang diperlihatkan oleh kelompok masyarakat konservasi dalam keberhasilan mengajak sebagian besar masyarakat untuk menjadi anggota konservasi penyu untuk desa Hadiwarno. Manfaat yang paling penting adalah berkurangnya penangkapan dan mengkonsumsi penyu yang menjadi kebiasaan masyarakat terdahulu. Sesuai dengan pernyataan Mar'at (1995) dalam Samsuri (2012), yang menyatakan bahwa sikap sebagai suatu yang dipelajari, oleh karena itu sifat sikap dapat dirubah.

Terdapat kesesuaian obyek sikap dengan lingkungan, artinya perilaku (pemanfaatan penyu) muncul karena adanya sikap. Alasan lainnya, sikap sudah tumbuh dan berkembang sejak dini dalam diri individu. Azwar (2007, dalam Samsuri, 2012), menyatakan bahwa sikap dipengaruhi oleh beberapa faktor yang meliputi 1) pengalaman pribadi. 2) orang lain yang dianggap penting. 3) kebudayaan. 4) media massa. 5) lembaga pendidikan dan agama. 6) emosional. Sikap merupakan salah satu fungsi instrumental atau fungsi manfaat, sehingga seseorang akan mempunyai sikap positif apabila terasa ada manfaat (Azwar, 2007).

Masyarakat (kepala keluarga) nelayan desa Hadiwarno memiliki sikap positif karena sudah memiliki kesadaran untuk menjaga keseimbangan lingkungan dan merasakan manfaat yang diperoleh dari pemanfaatan penyu melalui jalan konservasi. Mar'at (1982), menyampaikan bahwa sikap akan ada apabila diwujudkan dalam bentuk tingkah laku yang selalu didasarkan pada persepsi terhadap suatu objek dan persepsi seseorang terhadap suatu objek atau lingkunganya ditentukan oleh kebutuhannya. Dari hasil wawancara, FGD (Forum group discussion), dan interaksi dengan masyarakat desa Hadiwarno didapatkan bahwa sikap disebabkan oleh seringnya mendapatkan penyuluhan konservasi penyu dan berinteraksi dengan masyarakat konservasi, sehingga memunculkan kesadaran dan mengikat sikap peduli mereka terhadap pemanfaatan penyu.

Dapat disimpulkan, pengetahuan etnozoologi dalam hal ini adalah interaksi timbal balik secara positif masyarakat desa Hadiwarno dengan hewan penyu yang rendah dapat mempengaruhi perilaku melalui sikap yang sudah terbentuk dalam individu masyarakat. Terbentuknya sikap mengeni pemanfaatan penyu oleh masyarakat desa Hadiwarno lebih besar dipengaruhi kesadaran dan keadaan lingkungan. Pengetahuan etnozoologi mempengaruhi sikap sebesar $4,45 \%$, sedangkan berdasarkan statistik deskriptif menunjukkan tingkat pengetahuan etnozoologi tergolong sedang sebesar $61,46 \%$, yang berarti bahwa jika semakin meningkat atau tinggi pengetahuan etnozoologi masyarakat desa Hadiwarno maka akan semakin berpengaruh terhadap sikap. Temuan dalam penelitian ini, sejalan dengan hasil penelitian Kurniawati (2006), menemukan bahwa semakin tinggi pengetahuan etnozoologi seseorang semakin berpengaruh terhadap sikap.

Dari penelitian ini juga dihasilkan saran terkait dengan implementasi booklet 
sebagai media sosialisasi dan penyuluhan mengenai sikap dan pemanfaatan penyu oleh masyarakat desa Hadiwarno. Jika sosialisasi dan penyuluhan dimulai atau dilakukan pada masyarakat yang memiliki tingkat kesadaran rendah mengenai pentingnya melindungi dan melestarikan penyu, maka untuk lebih mudah diterima sebaiknya yang dibentuk atau terbentuk terlebih dahulu adalah sikap masyarakat mengenai pemanfaatan penyu yaitu terkait dengan manfaat atau keuntungan yang diperoleh. Seperti yang sudah dijelaskan sebelumnya, bahwa masyarakat desa Hadiwarno kabupaten Pacitan sadar akan pentingnya keseimbangan lingkungan yang ditunjukkan dengan kesungguhannya melakukan kegiatan konservasi penyu yang memberikan manfaat nyata bagi keseluruhan masyarakat di sektor ekowisata.

\section{Pembahasan Tahap 1: Hasil Penelitian Korelasional Kausal Jalur Blok 2}

Hasil uji korelasional kausal dengan menggunakan analisis jalur (path-analysis) "terdapat pengaruh langsung pengetahuan etnozoologi $\left(\mathrm{X}_{2}\right)$, terhadap pemanfaatan penyu (Y)". Berdasarkan hasil analisis hipotesis dalam penelitian ini, terungkap pengetahuan etnozoologi memberikan pengaruh langsung terhadap pemanfaatan penyu. Dari hasil perhitungan diperoleh besar pengaruh pengetahuan etnozoologi terhadap pemanfaatan penyu $6,10 \%$, artinya variabel lain juga berpengaruh terhadap pemanfaatan penyu.

Temuan dalam penelitian ini, sejalan dengan hasil penelitian Hidayatillah (2004), menyatakan semakin tinggi pengetahuan etnozoologi masyarakat semakin tinggi pula pemanfaatan penyu. Pengetahuan etnozoologi masyarakat desa Hadiwarno mengenai nilai-nilai tradisional dan kebudayaan dalam pemanfaatan penyu seperti; dukun sembelih penyu sebagai perantara menghilangkan kesialan atau petaka bagi masyarakat yang akan mengkonsumsi penyu, penanda musim bertelur dan cara mencari sarang dengan melihat jejak penyu yang diwariskan dari generasi ke generasi, dan paradigma yang salah bahwa penyu boleh dimakan karena sama seperti hasil laut lainnya. Sehingga, pengetahuan etnozoologi memberikan pengalaman langsung dalam pemanfaatan penyu.

Dari penelitian ini juga dihasilkan saran terkait dengan implementasi booklet sebagai media sosialisasi dan penyuluhan mengenai pemanfaatan penyu di daerah yang karakteristiknya sama atau mirip dengan masyarakat desa Hadiwarno. Jika memberikan sosialisasi dan penyuluhan tentang konservasi penyu dimulai atau dilakukan pada masyarakat yang memiliki pengetahuan etnozoologi tinggi, maka akan lebih mudah diterima jika lebih memperhatikan etik, emik, dan sosial budaya dalam masyarakat tersebut.

"Terdapat pengaruh langsung status ekonomi keluarga $\left(\mathrm{X}_{3}\right)$, terhadap pemanfaatan penyu (Y)". Berdasarkan hasil analisis hipotesis dalam penelitian ini, terungkap status ekonomi keluarga memberikan pengaruh langsung terhadap pemanfaatan penyu. Dari hasil perhitungan diperoleh besar pengaruh status ekonomi keluarga terhadap pemanfaatan penyu $3,49 \%$, artinya variabel lain juga berpengaruh terhadap pemanfaatan penyu.

Temuan dalam penelitian ini, sejalan dengan hasil penelitian Al Mudhar (1999) dan Samsuri (2012), menyatakan bahwa status ekonomi berpengaruh terhadap kegiatan pemanfaatan. Dalam penelitian ini terungkap bahwa pemanfaatan penyu dapat memberikan alternatif peningkatan ekonomi keluarga di desa Hadiwarno, melalui kegiatan program konservasi penyu berbasis wisata, diperoleh bantuan dari pemerintah daerah, instansi pendidikan, dan menteri kelautan. program tersebut dilakukan sebagai pengambilan solusi terhadap rendahnya status ekonomi masyarakat, sehingga dengan adanya dana atau biaya program konservasi penyu berbasis wisata dapat dilaksanakan. Hal ini seperti disampaikan oleh responden yang menyatakan bahwa ada berbagai fasilitas 
seperti kolam penangkaran penyu, gedung pertemuan, fasilitas MCK, akses jalan menuju lokasi konservasi penyu, meningkatnya wisatawan domestik maupun internasional, dan banyaknya aktifitas akademik untuk meneliti atau belajar langsung bahwa penyu harus dillindungi agar terjaga kelestariannya. Manfaat langsung yang dirasakan oleh masyarakat desa Hadiwarno dari kegiatan konservasi penyu berbasis wisata dapat meningkatkan status ekonomi dengan cara yang benar seperti menyediakan jasa penginapan, pemandu wisata (tour guide), penjual makanan di lokasi wisata dan masih banyak lagi. Semakin baik status ekonomi keluarga, maka semakin sedikit pemanfaatan penyu dengan alasan meningkatkan status ekonomi yang bersifat eksploitasi.

Dari penelitian ini juga dihasilkan saran terkait dengan implementasi booklet sebagai media sosialisasi dan penyuluhan mengenai pemanfaatan penyu di daerah yang karakteristiknya sama atau mirip dengan masyarakat desa Hadiwarno. Jika sosialisasi dan penyuluhan tentang konoservasi penyu dimulai atau dilakukan pada masyarakat yang status ekonominya baik, maka akan lebih mudah diterima dan dapat langsung dilaksanakan.

"Terdapat pengaruh langsung sikap $\left(\mathrm{X}_{4}\right)$, terhadap pemanfaatan penyu (Y)". Berdasarkan hasil analisis hipotesis dalam penelitian ini, terungkap sikap memberikan pengaruh langsung terhadap pemanfaatan penyu. Dari hasil perhitungan diperoleh besar pengaruh sikap terhadap pemanfaatan penyu $7,02 \%$, artinya variabel lain juga berpengaruh terhadap pemanfaatan penyu.

Temuan dalam penelitian ini, sejalan dengan hasil penelitian Hidayatillah (2004) dan Kurniawati (2006), menyatakan semakin tinggi sikap positif seseorang sangat berpengaruh terhadap pemanfaatan penyu. Hasil penelitian lain hampir sejenis yang dilakukan oleh Notani (1998) dalam Athiyaman (2002), bahwa sikap terhadap perilaku berpengaruh terhadap minat. Hal ini juga didukung oleh penelitian yang dilakukan Athiyaman (2002), bahwa sikap terhadap perilaku mempunyai pengaruh yang paling besar terhadap minat.

Nugroho (2003), menjelaskan bahwa sikap merupakan suatu evaluasi, perasaan emosional dan kecenderungan tindakan yang menguntungkan atau tidak menguntungkan dan bertahan lama dari seseorang terhadap beberapa objek atau gagasan. Pada dasarnya sikap mengarahkan orang-orang berperilaku secara konsisten terhadap objek yang serupa. Sikap seseorang membentuk suatu pola yang konsisten dan untuk mengubah suatu sikap mengharuskan penyesuaian dalam sikapsikap lain. Sikap terhadap perilaku terbentuk dari keyakinan dan evaluasi atas akibat atau konsekuensi yang muncul dari perilaku yang diyakininya.

Dari penelitian ini juga dihasilkan saran terkait dengan implementasi booklet sebagai media sosialisasi dan penyuluhan mengenai pemanfaatan penyu di daerah yang karakteristiknya sama atau mirip dengan masyarakat desa Hadiwarno. Jika sosialisasi dan penyuluhan tentang konservasi penyu dimulai atau dilakukan pada masyarakat yang memiliki sikap positif dalam pemanfaatan penyu, maka akan lebih mudah diterima dan dapat langsung dilaksanakan.

\section{Analisis Data Hasil Validasi Booklet dan Penentuan Keputusan Revisi Booklet}

Analisis kebermanfaatan media pembelajaran booklet "Panduan Teknis Konservasi Penyu". Karena booklet merupakan hasil penelitian, sehingga aplikasinya memeliki berbagai keuntungan; (1) ditinjau dari isi booklet dapat memberikan informasi tentang etnozoologi masyarakat dan pengetahuan tentang teknis pengelolahan konservasi penyu berbasis wisata yang benar, (2) ditinjau dari kegunaan dan tujuan pembelajaran, untuk meningkatkan perilaku masyarakat terkait dengan pemanfaatan penyu yang benar terlebih dahulu harus merubah sikap melalui pengetahuan yang diperolah dari pembelajaran. 
Berdasarkan hasil penelitian menunjukkan ada pengaruh tidak langsung pengetahuan etnozoologi melalui sikap sebesar 0,211, sedangkan pengaruh langsung pengetahuan etnozoologi terhadapa prilaku sebesar 0,247 , status ekonomi keluarga terhadapa sikap sebesar 0,187, dan pengaruh sikap terhadap prilaku pemanfaatan penyu sebesar 0,265 yang merupakan pengaruh terbesar. Sehingga, booklet dapat gunakan sebagai media pembelajaran untuk meningkatkan pengetahuan, sikap, prilaku, dan rujukan peningkatan status ekonomi masyarakat.

\section{KESIMPULAN DAN SARAN}

\section{Kesimpulan}

Berdasarkan tujuan dalam penelitian ini maka dapat disimpulkan sebagai berikut.

1. Tingkat pendidikan masyarakat desa Hadiwarno kabupaten Pacitan menunjukkan bahwa reponden yang tamat SMP dan SMA merupakan persentase paling besar yaitu $53,1 \%$, hal ini menunjukkan bahwa latarbelakang pendidikan mengalami masa transisi. Hal ini dibuktikan dengan nilai Kolmogorov-Smirnov kurang dari nilai signifikansi $0,05 \quad(\mathrm{p}<0,05)$ maka dinyatakan data tidak normal dan tidak bisa diuji dengan analisis jalur.

2. Tingkat pengetahuan etnozoologi masyarakat mengenai pemanfaatan penyu tergolong sedang dengan persentase sebesar $61,46 \%$.

3. Tingkat status ekonomi keluarga desa Hadiwarno tergolong tingkat status ekonomi sangat rendah karena termasuk kelompok ekonomi < 2000 dengan presentase sebesar 99,0\%.

4. Sikap masyarakat terhadap pemanfaatan penyu di desa Hadiwarno menunjukkan bahwa, tingkat sikap masyarakat tergolong sedang dengan persentase sebesar $51,04 \%$.

5. Tingkat perilaku masyarakat terkait pemanfaatan penyu di desa Hadiwarno tergolong sedang dengan nilai sebesar $42,72 \%$.

6. Hubungan antara pengetahuan etnozoologi dengan status ekonomi keluarga dengan nilai korelasi sebesar 0,046 artinya antara pengetahuan etnozoologi dengan status ekonomi keluarga tidak diperolah hubungan.

7. Analisis Blok 1, tidak ada pengaruh secara bersama-sama antara pengetahuan etnozoologi dan status ekonomi keluarga terhadap sikap pada taraf signifikan $\mathrm{p}=0,121>0,05$. Analisis Blok 1 Model 2 melalui metode trimming, ada pengaruh secara individu pengetahuan etnozoologi terhadap sikap dengan nilai signifikan $0,039<0,05$.

8. Analisis Blok 2, terdapat pengaruh secara bersama-sama dan sangat signifikan pengetahuan etnozoologi, status ekonomi keluarga, dan sikap terhadap pemanfaatan penyu, pada taraf signifikan $\mathrm{p}=0,001<0,05$ dengan sumbangan efektif sebesar 16,2\%. Terdapat pengaruh secara individu pengetahuan etnozoologi terhadap pemanfaatan penyu sangat signifikan $\mathrm{p}$ $=0,013<0,05$ dengan sumbangan efektif sebesar $6,10 \%$. Terdapat pengaruh secara individu status ekonomi keluarga dengan nilai signifikan 0,041 < 0,05 dengan sumbangan efektif sebesar $3,49 \%$. Terdapat pengaruh secara individu sikap terhadap pemanfaatan penyu dengan nilai signifikan $0,032<$ 0,05 dengan sumbangan efektif sebesar $7,02 \%$.

9. Terdapat pengaruh tidak langsung pengetahuan etnozoologi melalui sikap terhadap pemanfaatan penyu dengan sumbangan sebesar 0,06\%. Tidak terdapat pengaruh tidak langsung status ekonomi keluarga melalui sikap terhadap pemanfaatan penyu.

\section{Saran}

Berdasarkan kegunaan dalam penelitian ini, maka dapat disarankan halhal sebagai berikut. 
1. Pelaksanaan kegiatan sosialisasi dan penyuluhan, mengenai pemanfaatan penyu pada daerah yang karakteristik masyarakatnya sama atau mirip dengan desa Hadiwarno kabupaten Pacitan sebaiknya dilihat berdasarkan pengetahuan etnozoologi, status ekonomi dan sikap. Sedangkan, penggunaan media booklet untuk sosialisasi dan penyuluhan, hendaknya berdasarkan hasil penelitian.

2. Sosialisasi dan penyuluhan mengenai pengambangan potensi bahari khususnya pemanfaatan penyu, hendaknya melihat variabel sosial misalnya, latar belakang pendidikan, pengetahuan etnozoologi, status ekonomi keluarga, dan sikap, sehingga masyarakat tidak hanya memanfaatakan potensi daerah, tetapi masyarakat juga memahami dengan benar apa yang dilakukan.

3. Temuan penelitian ini dapat menjadi rekomendasi kepada pemerintah dan masyarakat agar dapat memahami dan mengembangkan potensi kelautan, yang dapat dimanfaatkan, menggalakkan konservasi penyu dengan memperhatikan berbagai faktor, yaitu tingkat latar belakang pendidikan, pengetahuan etnozoologi, status ekonomi dan sikap dari masyarakat.

4. Lembaga pendidikan formal yang ada sekarang ini, sudah selayaknya memikirkan komponen kurikulum yang benar-benar dapat memberi efek positif terhadap lingkungan dengan memperhatikan potensi daerah tempat peserta didik bertempat tinggal. Sedangkan untuk masyarakat putus sekolah, sebaiknya dari tokoh masyarakat atau masyarakat intelek membentuk pendidikan luar sekolah dan memprogram kebijakan untuk membantu memberi bekal ajar kepada masyarakat dalam bentuk penyuluhan serta dengan bimbingan yang berkesinambungan. Selain itu, membentuk kader-kader pemerhati lingkungan tentang pemeliharaan lingkungan dan konservasi penyu.

5. Kepada peneliti selanjutnya yang hendak melakukan penelitian sejenis di tempat berbeda atau sama, dapat menjadikan hasil penelitian ini sebagai referensi dan sebaiknya menambah variabel dengan melihat hal-hal lain dari yang sudah dipaparkan dalam penelitian ini serta mengimplementasikan dalam bentuk produk yaitu bahan pembelajaran masyarakat yang mendukung.

\section{DAFTAR RUJUKAN}

Al Mudhar. 1999. Keterkaitan antara Faktor Sosial, Faktor Ekonomi, Faktor Budaya, Pengetahuan, dan Sikap dengan Manifestasi Perilaku Ibu-Ibu Rumah Tangga dalam Pengelolaan Sampah Rumah Tangga di Kotamadya Surabaya. Disertasi tidak diterbitkan. Malang: Program Pascasarjana IKIP Malang.

Arshad, 2003. Usaha Menyelamatkan Penyu Perlu Kerjasama ASEAN, http://www.jphpk.gov.my/Ogos0352 023.htm. Diakses 10 Juni 2013.

Arsyad, Azhar. 2009. Media Pembelajaran .Jakarta: Raja Grafindo Persada.

Azwar, S. 2007. Sikap Manusia Teori dan Pengukurannya. Yogyakarta: Pustaka Pelajar.

Dahuri, 2001. Kebijaksanaan dan Program Sektor Kelautan dan Perikanan dalam Rangka Pemulihan Ekonomi Menuju Bangsa Indonesia yang Maju Makmur dan Berkeadilan. Jakarta: Departemen kelautan dan Perikanan RI.

Hamdanah, 2010. Pengaruh Kondisi Sosial Ekonomi Keluarga terhadap Prestasi Belajar Siswa di Desa Plukaran Kecamatan Gembong Kabupaten Pati (Studi Kasus di Desa Plukaran). Skripsi tidak diterbitkan. Kudus: Jurusan Syari'ah, Sekolah Tinggi Agama Islam Negeri Kudus.

Hariri, Ahmad. 1999. Periklanan Masa Kini. PT. Adi Cipta. Surabaya. 
Hidayatillah, Martinova Fi. 2004. Studi Etnozoologi pada Masyarakat Bali Khususnya Desa Pekraman Kelurahan Sarangan Wilayah Denpasar propinsi Bali. Skripsi tidak diterbitkan. Malang: Prodi Pendidikan Biologi, FKIP UMM.

Indonesian Nature Conservation Database. 2003. Status Penyu Laut (Chelonidae) Berdasarkan IUCN. Http://www.nature conservation.id/chelonidae.html. Diakses 10 Januari 2014.

Kurniawati, Dwi Farida Ari. 2006. Studi Etnozoologi Penyu pada Masyarakat Pesisir Di Kecamatan Ngadirojo Kabupaten Pacitan. Skripsi tidak diterbitkan. Malang: Prodi Pendidikan Biologi, FKIP UMM.

Mar'at, 1981. Sikap Manusia, perubahan serta pengukuran. Galia. Jakarta: Fakultas Psikologi. Universitas Pajajaran Bandung.

Peraturan Pemerintah Republik Indonesia no 7 tahun 1999 tentang Pengawetan tumbuhan dan satwa langka.

Pramoto, 2004. Evaluasi Kebijakan Perlindungan Penyu Hijau Di Indonesia. Pusat Penyelamatan Satwa Cikananga. Sukabumi: KSDA Jawa Barat.

Prihanta, 2007. Problematika Kegiatan Konservasi Penyu di Taman Nasional Meru Betiri. Laporan penelitian Pengembangan Iptek tidak diterbitkan. Malang: FKIP Universitas Muhammadiyah Malang.

Putra, S, Ketut. 1997. Program Penyuluhan dan Pendidikan mengenai Konservasi Penyu di Bali (Penyertaan Tema Konservasi Kedalam Budaya Masyarakat Bali). Makalah; WorkshopPenelitian dan Pengelolaan penyu di Indonesia. Bogor: Direktorat Jenderal Perlindungan Hutan dan Pelestarian Alam.

Samsuri, 2012. Hubungan Antara Latar Belakang Pendidikan Formal, Pengetahuan, Status Ekonomi dan
Sikap dengan Upaya Masyarakat Mengenai Budidaya Grynops verstegii (Giig) Domke serta Implikasinya Bagi Pembelajaran Masyarakat Petani Gaharu Di Pulau Lombok. Tesis tidak diterbitkan. Malang. PPs UM.

Setiadi, Nugroho J, 2003. Perilaku Konsumen: Konsep dan Implikasi untuk Strategi dan Penelitian Pemasaran, Jakarta: Prenada Media.

Sutomo, 2009. Filsafat Ilmu Kealaman dan Etika Lingkungan. Malang: Universitas Negeri Malang Press.

Troeng, Sebastian. 1997. "Pemanfaatan Penyu Laut". Makalah; Workshop Penelitian dan Pengelolaan Penyu Indonesia. Bogor: Direktorat Jenderal Perlindungan Hutan dan Pelestarian Alam. 